\title{
Intrinsic and extrinsic factors influencing the clinical course of B-cell chronic lymphocytic leukemia: prognostic markers with pathogenetic relevance
}

\author{
Michele Dal-Bo ${ }^{1}$, Francesco Bertoni ${ }^{2}$, Francesco Forconi ${ }^{3}$, \\ Antonella Zucchetto ${ }^{1}$, Riccardo Bomben ${ }^{1}$, Roberto Marasca ${ }^{4}$, Silvia Deaglio ${ }^{5}$, \\ Luca Laurenti6, Dimitar G Efremov7, Gianluca Gaidano ${ }^{8}$, Giovanni Del \\ Poeta $^{9}$ and Valter Gattei*1
}

\begin{abstract}
Address: ${ }^{1}$ Clinical and Experimental Onco-Hematology Unit, Centro di Riferimento Oncologico, I.R.C.C.S., Aviano (PN), Italy, ${ }^{2}$ Laboratory of Experimental Oncology and Lymphoma Unit, Oncology Institute of Southern Switzerland, Bellinzona, Switzerland, ${ }^{3}$ Division of Hematology and Transplant, Department of Clinical Medicine and Immunological Sciences, University of Siena, Siena, Italy, ${ }^{4}$ Division of Hematology -

Department of Oncology and Hematology-University of Modena and Reggio Emilia, Modena, Italy, ${ }^{5}$ Laboratory of Immunogenetics, Department of Genetics, Biology and Biochemistry and CeRMS, University of Turin, Turin, Italy, "Hematology Institute, Catholic University "Sacro Cuore", Rome, Italy, ${ }^{7}$ Molecular Hematology, ICGEB Outstation-Monterotondo, Rome, Italy, ${ }^{8}$ Division of Hematology - Department of Clinical and Experimental Medicine \& BRMA - Amedeo Avogadro University of Eastern Piedmont, Novara, Italy and ${ }^{9}$ Chair of Hematology, S.Eugenio Hospital and University of Tor Vergata, Rome, Italy

Email: Michele Dal-Bo - micheledalbo@gmail.com; Francesco Bertoni - frbertoni@mac.com; Francesco Forconi - forconif@unisi.it; Antonella Zucchetto - antonellazucchetto@libero.it; Riccardo Bomben - riccardo.bomben@gmail.com; Roberto Marasca - marasca@unimo.it; Silvia Deaglio - silvia.deaglio@unito.it; Luca Laurenti - 1.laurenti@rm.unicatt.it; Dimitar G Efremov - efremov@icgeb.org;

Gianluca Gaidano - gaidano@med.unipmn.it; Giovanni Del Poeta - g.delpoeta@tin.it; Valter Gattei* - vgattei@cro.it

* Corresponding author
\end{abstract}

Published: 28 August 2009

Journal of Translational Medicine 2009, 7:76 doi:I0.1 I86/1479-5876-7-76
Received: 27 June 2009

Accepted: 28 August 2009

This article is available from: http://www.translational-medicine.com/content/7/I/76

(C) 2009 Dal-Bo et al; licensee BioMed Central Ltd.

This is an Open Access article distributed under the terms of the Creative Commons Attribution License (http://creativecommons.org/licenses/by/2.0), which permits unrestricted use, distribution, and reproduction in any medium, provided the original work is properly cited.

\begin{abstract}
B-cell chronic lymphocytic leukemia (CLL), the most frequent leukemia in the Western world, is characterized by extremely variable clinical courses with survivals ranging from I to more than 15 years. The pathogenetic factors playing a key role in defining the biological features of CLL cells, hence eventually influencing the clinical aggressiveness of the disease, are here divided into "intrinsic factors", mainly genomic alterations of CLL cells, and "extrinsic factors", responsible for direct microenvironmental interactions of CLL cells; the latter group includes interactions of CLL cells occurring via the surface $B$ cell receptor (BCR) and dependent to specific molecular features of the BCR itself and/or to the presence of the BCR-associated molecule ZAP-70, or via other non$B C R$-dependent interactions, e.g. specific receptor/ligand interactions, such as $C D 38 / C D 3$ I or CD49d/VCAM-I. A putative final model, discussing the pathogenesis and the clinicobiological features of CLL in relationship of these factors, is also provided.
\end{abstract}

\section{Introduction}

B-cell chronic lymphocytic leukemia (CLL) is a monoclonal expansion of small mature B lymphocytes accumu- lating in blood, marrow, and lymphoid organs. Despite a remarkable phenotypic homogeneity, CLL is characterized by extremely variable clinical courses with survivals 
ranging from one to more than 15 years [1]. In this regard, specific chromosomal aberrations (i.e. 17p-, 11q- or +12), as well as the presence of an unmutated (UM) rather than mutated (M) status of immunoglobulin (IG) heavy chain variable $(I G H V)$ genes, or expression levels for ZAP-70, CD38 and CD49d exceeding the value of an established threshold, have been reported to correlate with a poor clinical outcome in CLL [2-8].

In the present review, the main factors playing a role in defining the biological features of CLL cells, hence eventually influencing the clinical aggressiveness of the disease, are divided into "intrinsic factors", mainly genomic alterations of CLL cells, and "extrinsic factors", responsible for direct micro-environmental interactions of CLL cells.

\section{Intrinsic factors}

Under the terms "intrinsic factors" are gathered the major genomic alterations associated with a CLL phenotype. Such alterations can be either primarily responsible for the first step(s) of neoplastic transformation of $\mathrm{B}$ cells (primary genetic lesions, e.g. 13q14.3 deletion, see below) or acquired during disease progression, also as a consequence of microenvironmental interactions (i.e. secondary genetic lesions). Telomer lenght too was included in this chapter, although often consequence of environmental factors affecting cell proliferation (see below).

It is common notion that, differently from other B-cell lymphoid neoplasms, CLL is characterized by recurrent DNA gains and losses and not by the presence of specific chromosomal translocations. However, using either improved protocols to obtain informative metaphases $[9,10]$ or microarray-based comparative genomic hybridization [11], chromosomal abnormalities can now be detected in over $90 \%$ of patients [9]. Only a fraction of the events are balanced translocations, whilst the vast majority of them are unbalanced translocations (see below), determining losses or gains of genomic material $[9,10]$. Specific genomic events are associated with a different clinical outcome and, the frequency of specific genomic events varies between CLL bearing Mutated (M) and
Unmutated (UM) IGHV genes (see below for IGHV molecular features). The recurrent chromosomal aberrations are summarized in Table 1.

\section{$13 q 14.3$ deletion}

The most common lesion in CLL is chromosome 13q14.3 deletion, occurring in half of the cases [4]. The deletion is often interstitial and can be homozygous in up to $15 \%$ of the cases [4]. When it represents the only lesion it is associated with a good clinical outcome, and with the presence of Mutated IGHV genes [4,10,12]. A selective advantage, possibly proning $\mathrm{B}$ cell clones to additional mutations, could be conferred because of the high frequency of $13 q$ deletion [13].

The pathogenetic role of $13 \mathrm{q}$ deletion in CLL is not fully clear, although its high frequency has suggested a primary and central role in the CLL transformation process [14]. Several regions between 130 and $550 \mathrm{~kb}$ were described, all comprising a minimal deleted region of $29 \mathrm{~kb}$ located between exons 2 and 5 of DLEU2 [15]. The deleted region always comprises the locus coding for two microRNAs (miRNAs), hsa-mir-16-1 and hsa-mir-15a [15], but it can also include the region coding for the retinoblastoma gene (RB1) [16]. mir-16-1 and mir-15a are deleted or downregulated in the majority (about 70\%) of CLL [14]. miRNAs represent a large class of regulating non-coding small RNA molecules, acting by binding messenger RNAs and determining their degradation or inhibition of translation [17]. Over-expression of the anti-apoptotic BCL2, due to the reduced negative regulation by mir-16-1 and mir-15a, has been proposed along with other several genes often involved in cell cycle and/or programmed cell death regulation such as MCL1, ETS1 and JUN [16,18-20]. Additional studies are needed to identify the genes actually involved in CLL pathogenesis via the $13 \mathrm{q}$ deletion.

\section{Trisomy 12}

The trisomy 12 bears an intermediate prognosis and is only marginally associated with an UM IGHV gene status $[10,12]$. The $12 \mathrm{q} 22$ segment contains CLLU1 which is the first gene that was considered specific for CLL cells, but no

Table I: Intrinsic factors with prognostic relevance

\begin{tabular}{|c|c|c|c|}
\hline Karyotype & $\%$ of cases, range ${ }^{a}$ & Prognosis & Known and/or putative involved genes \\
\hline I3q | 4.3 loss & $14-40$ & $\operatorname{good}^{b}$ & mir-I6-I; mir- $15 a$ \\
\hline I I q22-23 loss & $10-32$ & bad & ATM \\
\hline trisomy 12 & $11-18$ & intermediate & CLLUI \\
\hline I7p|3.I loss & $3-27$ & bad & TP53 \\
\hline
\end{tabular}

aAccording to [30];

blf the sole genetic aberration. 
difference in CLLU1 protein expression in patients with or without trisomy 12 has been reported [21,22]. Of note, high CLLU1 expression levels has been demonstrated to predict poor clinical outcome in CLL of younger patients [23].

\section{I q22-q23 deletion}

CLL harboring 11q22-q23 deletion tend to present a rapidly evolving disease [4]. This lesion targets the gene coding for ATM (ataxia telangiectasia mutated), which is mutated in approximately $15 \%$ of CLL, not necessarily bearing concomitant 11q losses [24]. The presence of 11q deletion or of ATM mutations determines poor prognosis, and it is more common among cases with UM IGHV and ZAP-70 or CD38 positivity, or experiencing bulky lymphadenopathies $[4,10,24-28]$. ATM is involved in the DNA repair and its inactivation impairs the response of CLL cells to chemotherapy $[26,28]$. It has been suggested that, for the complete lack of ATM function, the other ATM allele should present mutations [29]. Since ATM mutations are present in one third of the $11 \mathrm{q}$ - cases, the poor prognosis of $11 \mathrm{q}$ - patients has been suggested to depend on mechanisms involving other genes affecting cell cycle regulation and apoptosis (e.g. NPAT, CUL5, PPP2R1B) $[28,29]$.

\section{I $7 p / 3.1$ deletion}

The recurrent $17 \mathrm{p} 13.1$ deletion, affecting TP53, occurs only in a small fraction of CLL patients at diagnosis [4]. It confers the worst prognosis among all the genetic lesions [4], and it is more common among patients bearing other poor prognostic factors, such as UM IGHV, or ZAP-70 and CD38 expression $[4,10,27,30]$. TP53 is a transcription factor activated by strand breaks in DNA that is involved in triggering cell apoptosis and/or cell-cycle arrest, with the aim to maintain the genome integrity by hindering clonal progression [31]. The activation of TP53 is tightly regulated by the MDM2 (murine double minute-2) gene [32], whose expression is regulated in part by a TP53 responsive promoter. MDM2, an E3 ubiquitin ligase for TP53 and itself, controls TP53 half-life via ubiquitin-dependent degradation [33-35]. In cells with functional TP53, the TP53 activity is primarily inhibited through direct and tonic interaction with the MDM2 protein [32]. Treatment of various tumor cells with inhibitors of the MDM2-TP53 interaction results in rising TP53 levels and subsequent induction of cell cycle arrest and apoptosis [36]. Thus, small-molecule inhibitors that block the MDM2-TP53 interaction, like Nutlins, could represent a new therapeutic strategy for treatment of CLL patients [37].

In CLL, TP53 is mutated in about $10 \%$ of patients at presentation and in $10 \%$ to $30 \%$ of patients with pretreated disease [38-40]. TP53 can be inactivated by somatic mutations which can occur in the presence or in the absence of any genomic loss $[2,25]$. Whereas up to two-thirds of del17p13 CLL also harbor TP53 mutations, a fraction of CLL carries TP53 mutations without del17p13 [2,25,41], and TP53 mutations have been shown to have a negative prognostic relevance also in the absence of TP53 deletion [42]. Besides TP53 mutations and deletion, other mechanisms of TP53 dysfunction may be operative in CLL $[28,43-46]$. These mechanisms may involve the ATM and MDM2 genes that regulate TP53 function at the protein level $[28,46]$. ATM is related to TP53 because it acts as a TP53 kinase, although ATM deletions do not confer a disease as aggressive as it occurs in TP53 deletions [47]. Notably, ATM mutations and MDM2 polymorphisms causing aberrant MDM2 expression have been shown to harbor prognostic relevance in CLL $[28,43,46]$.

TP53 inactivation is associated with a poor response to chemotherapy, including alkylating agents and purine analogues [2]. This suggested the need, for patients affected by CLL with disrupted TP53 function, of TP53 independent therapeutic agents $[26,41,48,49]$. In this regard, CLL that at diagnosis presented del17p13 without TP53 mutations displayed a significantly longer time to chemorefractoriness than CLL with TP53 mutations already at diagnosis [42]. In addition, CLL with del17p13 only acquired TP53 mutations at chemorefractoriness [42].

Chromosomal translocations and other chromosomal abnormalities Historically, chromosomal translocations were considered infrequent events in CLL. However, relatively recent studies reported an unexpected high frequency (approximately 20\%) of reciprocal translocations when successful methods for CLL B cell stimulation are employed, e.g. by utilizing CD40 ligand or oligonucleotides and IL-2 as stimuli $[9,50]$. These studies have also correlated chromosomal translocations with shorter treatment-free survival and overall survival. Together with the more common chromosomal abnormalities, genome wide screening has found other alterations consisting of clonal monoallelic and biallelic losses as well as gains such as duplications, amplifications and trisomies [51-54]. These alterations concern relatively small chromosomal regions spread throughout the CLL genome [51-54]. Moreover, these gains or losses enable the detection of clonal variants that differ at several loci [52]. The biologic and prognostic significance of these other recurrent genomic aberrations is not known. Patients bearing three or more aberrations or chromosomal translocations might have a worse prognosis [9]. Prospective trials and a more widespread use of genome wide techniques to assess CLL genome will help to identify further genetic prognostic markers.

\section{Telomere length}

An interesting feature of CLL is its heterogeneity in terms of telomere length and telomerase (hTERT) activity [5558]. Short telomeres and high hTERT activity are associ- 
ated with worse clinical outcome, with an UM IGHV gene status, with high ZAP-70, CD38, and CD49d expression, as well as with specific cytogenetic abnormalities $[56,58,59]$. Regarding this latter point, short telomeres are frequently associated with $11 \mathrm{q}$ or $17 \mathrm{p}$ deletions whereas long telomeres are present in 13q- patients [58]. Normal $B$ cells in the germinal center present high hTERT activity, and telomere elongation has been shown to occur at the same time of the somatic hypermutation process [60], thus, B cells with M IGHV genes present longer telomeres than B cells with UM genes. Therefore it is conceivable that different B cells already present different telomere length before the leukemic transformation; alternatively, kinetic characteristics of CLL cells can determine differences in telomere length, and telomere shortening might be a consequence of $11 \mathrm{q}$ - or $17 \mathrm{p}$ - aberration that, together with ZAP-70, CD38 and CD49d overexpression, results in a more rapid CLL cell turnover, facilitating survival and cell-cycle progression $[58,61]$.

\section{Clinical implications of intrinsic factors}

In the clinical practice, the detection, by using a panel of interphase fluorescence in situ hybridization (FISH) probes, at least including 13q14.3, 11q22-23 and $17 \mathrm{p} 13.1$ deletions and trisomy 12 , should always be part of the initial diagnostic procedure. Although only a small portion of patients presents genetic abnormalities considered bad prognostic markers, such as $17 \mathrm{p}$ or $11 \mathrm{q}$ deletions, at the onset, these alterations can appear during the clinical course, more often in patients carrying other poor prognostic markers (such as UM IGHV mutational status or high ZAP-70, CD38 and CD49d expression) [38,39]. Given that acquisition of new cytogenetic abnormalities may influence the response to therapy, FISH analysis should be repeated at the time of progression or before therapy selection. Given its valuable prognostic impact, analysis of TP53 mutational status could be also advisable in the phase of progressive disease.

\section{Extrinsic factors}

Extrinsic factors are responsible for direct interaction of CLL cells with other micro-environmental cell populations. In the present review, we focused on interactions of CLL cells occurring via the surface B cell receptor (BCR) and dependent on specific molecular features of the BCR itself and/or on the presence of the BCR-associated molecule ZAP-70, or via other non-BCR-dependent interactions, e.g. the CD38/CD31 or CD49d/VCAM-1 receptor/ ligand interactions (Table 2). Differences in IGHV mutational status and in BCR functionality suggested a different cell of origin for CLL with UM versus CLL with M IGHV gene mutational status. Despite this, CLL cases appear very homogenous when their gene expression profiles are compared with those of normal or other neoplastic B-cells $[62,63]$. For this reason CLL is nowadays believed to derive from subsets of marginal zone memory B-cells that have undergone either a T-cell dependent or Tcell independent maturation $[64,65]$.

\section{The BCR in CLL}

BCR is a multimeric complex constituted of a membranebound IG glycoprotein and a heterodimer IG $\alpha / \mathrm{IG} \beta$ (CD79A/CD79B), located on the surface of B cell. The IG glycoprotein is composed by two identical heavy chains $(\mu, \delta, \alpha, \gamma$ or $\varepsilon$ ) and two identical light chains: $\kappa$ or $\lambda$. Both heavy and light chains have two variable regions (IGHV or $I G(K / L) V)$ that mediates antigen contact and vary extensively between IG, along with a constant region that is responsible for the effector activities. For heavy chain, the variable region is encoded by three gene segments: variable (IGHV), diversity (IGHD) and joining (IGHJ), whereas the variable regions of the light chains are generated from

Table 2: Extrinsic factors with prognostic relevance

\begin{tabular}{llll}
\hline Factors & Negative prognosis if expressing & $\begin{array}{l}\text { Cases with unfavourable values, mean } \\
\%(\text { range) }\end{array}$ & $\begin{array}{l}\text { Putative mechanisms responsible for } \\
\text { unfavourable prognosis }\end{array}$ \\
\hline BCR & $\begin{array}{l}\text { - UM IGHV } \\
- \text { stereotyped BCR? } \\
-M \text { IGHV3-23? }\end{array}$ & $42.3(40-46)^{\mathrm{a}}$ & $\begin{array}{l}\text { - high reactivity or polyreactivity } \\
\text { - superantigens recognition? }\end{array}$ \\
\hline ZAP-70 & $>20 \%$ & $44.7(36-52)^{\mathrm{b}}$ & $\begin{array}{l}\text { - tyrosine phosphorylation } \\
\text { - calcium influx } \\
\text { - chemokine sensitivity }\end{array}$ \\
\hline CD38 & $>30 \%$ & & - microenviromental interactions (CD38/CD3I) \\
\hline CD49d & $>30 \%$ & $36.3(30-44)^{\mathrm{c}}$ & - microenviromental interactions \\
(CD49d/VCAM-I; CD49d/Fibronectin)
\end{tabular}

aDeduced from $[25,91,92]$;

bDeduced from [7,114,116];

cDeduced from [25, 127, 128];

dDeduced from $[8,150,152]$. 
$I G(K / L) V$ and $I G(K / L) J$ segments. Both for heavy and light chains, the segments involved in $V(D) J$ recombination confer diversity by random and imprecise rearrangement during B-cell development in the bone marrow. The consequent protein sequences mainly differ in the complementary-determining-region-3 of the heavy (HCDR3) and light (K/LCDR3) chains. Diversity is further enhanced by the somatic hypermutation (SHM) process, which requires BCR cross-linking by the antigen, cellular activation, cooperation of T lymphocytes and other cells, and introduces point mutations in variable regions of rearranged immunoglobulin heavy and light chains [66]. Another process physiologically occurring during B cell differentiation is the so-called class-switch recombination (CSR), which modify the constant region of heavy chains, thus altering the effector functions of IG [66].

The BCR has always been a key molecule to understanding CLL, initially only due to the surface IG that were utilized to make or support a correct diagnosis [67]. Surface IG are usually IGM/IGD, expressed at low/dim intensity [47]. The explanation of the low/dim expression level of BCR is still unclear [47]. CLL expressing IGG is a relatively rare variant whose origin and antigenic relation with the most common IGM/IGD variant is still not completely clear [68].

Studies of the molecular structure of the BCR in CLL are suggesting evidences of a promoting role of the antigen encounter. A first evidence has been provided by analysis of IGHV genes starting in the early 90s' that revealed that $50 \%$ of CLL had M IGHV genes [69-71]. These mutations often fulfill the criteria for selection by antigen with more replacement mutations in heavy chain complementarity determining regions (HCDR) and less in heavy chain framework regions (HFR), which permits the development of a more specific antigen-binding site by maintaining the necessary supporting scaffold of BCR [6,72-76].

From a clinical point of view, in 1999, two mutually confirmatory papers demonstrated that somatic mutations correlated with more benign diseases. In fact, a CLL subgroup with very unfavourable clinical outcome presents none or few $(<2 \%)$ mutations (UM CLL) in IGHV genes, respect to the closest germ line sequence. CLL cells of this particular subgroup seem to receive continuous antiapoptotic and/or proliferating microenvironmental stimuli via BCR leading to a more aggressive disease than the subgroup with $\mathrm{M}$ configuration of $I G H V$ genes $(\geq 2 \% ; M$ CLL), respect to the closest germ line sequence $[3,77]$. A difference in outcome was also demonstrated in patients receiving an autologous stem-cell transplant (ASCT); all patients with UM IGHV genes undergoing ASCT relapsed and progressed after a 4-year follow-up, while most with
M IGHV genes remained in molecular remission at this stage [78].

Activation-induced cytidine deaminase (AID), an enzyme involved in SHM and CSR during normal B cell differentiation [79], was found to be upregulated in UM CLL cells [80], and, even if expression could be restricted to a small fraction of the clone $[6,81]$, AID seems to be functional with generation of isotype-switched transcripts and mutations in the pre-switch $\mu$ region $[82,83]$. AID upregulation causes mutation in genes related with an aggressive disease (e.g. BCL6, PAX5, MYC, RHOH) [84,85]. Furthermore, a relation of AID expression with deletions in $11 \mathrm{q}-$ and loss of TP53 has been found [86].

\section{BCR stereotypes in CLL (see Figure I)}

CLL have a biased use of some specific gene segments. For example, a preferential use of IGHV1-69 in the UM CLL and IGHV4-34 and IGHV3-23 in the M CLL subgroups has been documented [87-92]. In addition, several groups reported the existence of subsets of CLL cases carrying BCR characterized by non-random pairing of specific $I G H V$, highly homologous or identical HCDR3 often associated with a restricted selection of IGVK or IGVL light chains (the so-called "stereotyped BCR") [89-97]. These stereotyped BCR have been detected in more than $20 \%$ of CLL cases $[89,91,92,97]$; the non-random composition of the expressed BCR on the CLL cells with IG binding lead to hypothesize a specificity for similar/identical antigens $[89,91,92,98]$.

The chance of carrying a stereotyped BCR is higher for UM CLL [94]. The vast majority of the clusters shared by distinct, and in several cases geographically distant, datasets ("common" clusters) were composed by UM cases [89,91-

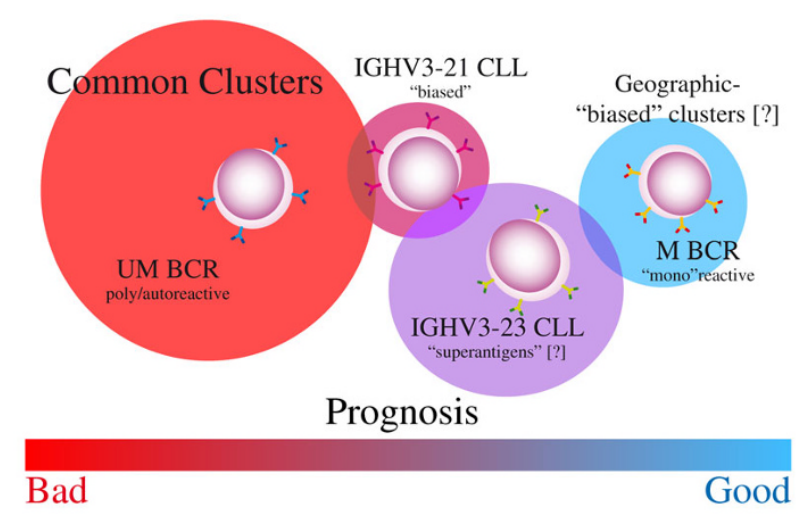

Figure I

CLL subsets with distinct BCR features and their correlation with prognosis. Question marks in parenthesis indicate data that has to be confirmed by further investigations. 
$94,97]$. In particular, these UM clusters included cases that seem to express both autoreactive and polyreactive BCR, allegedly deriving from the B cell compartment devoted to the production of natural antibodies [96,98,99]. Among "common" clusters, of particular clinical interest is a cluster composed by UM CLL with stereotyped BCR expressing genes from the IGHV1 gene family other than IGHV169 (IGHV1-2,IGHV1-18, IGHV1-3,IGHV1-46, IGHV7-41), homologous HCDR3 bearing the QWL amino acid motif, and IGKV1-39 light chains [89,91,92]. The prognosis of CLL expressing this stereotyped BCR is poor either if compared to all the other patients affected by M or UM CLL, or only to the cases expressing the same IGHV genes but without the same stereotyped BCR [89,92].

Among the few M clusters that are shared by the majority/ totality of the datasets, there are two clusters, both expressing IGG, composed by cases expressing IGHV4-34 and IGHV4-39, respectively [89,91,92,100,101]. Specific cluster-biased genomic aberrations have been found; $13 \mathrm{q}-$ has been associated with IGHV4-34/IGKV2-30 cluster while trisomy 12 has been associated with the IGHV4-39/ IGKV1-39 cluster [101]. Interestingly, the latter cluster has been associated with the development of Richter syndrome in CLL [102,103]. Other clusters, mainly composed by $\mathrm{M}$ cases and expressing IGHV3 subgroup genes, are less frequent and might be subjected to a geographical bias.

Finally, of particular interest is a group of IGHV3-21 CLL, composed by cases with either UM or M IGHV genes, that expressed a stereotyped BCR characterized by an unusually short and highly homologous HCDR3 associated with IGLV3-21 [88,90,93,104,105]. Of note, a significantly skewed representation of this particular cluster has been well documented in different European and nonEuropean countries and even in different regions from the same country $[88,90,104,105]$. From a clinical standpoint, evidence is provided that patients belonging to IGHV3-21/IGLV3-21 CLL cluster have shorter TTT when compared to all M CLL and to M CLL expressing IGHV321 but not included in this stereotyped cluster $[88,90,92]$. Although the issue is still controversial [88,105], the molecular basis for a more aggressive clinical behaviour of CLL belonging to IGHV3-21/IGLV3-21 CLL cluster is also suggested by gene expression profiling and immunophenotypic analyses [90]. The notion that only patients affected by CLL belonged to the IGHV3-21/IGLV3-21 cluster experience a more progressive disease may have important implications given the proposal of using IGHV3-21 expression to drive clinical decision in prospective trials $[27,49]$.

Non-stereotyped BCR in CLL (see Figure I)

Considering the IGHV gene usage and relating it with the distribution of IGHV gene in stereotyped BCR clusters, it has been observed that cases expressing the IGHV3-23 gene are constantly absent from stereotyped BCR clusters [106], despite that IGHV3-23 is the second most frequently used and usually M IGHV gene in CLL [89,90,92]. A possible explanation justifying the absence of IGHV3-23 genes from clusters of stereotyped BCR is the possibility that IGHV3-23-expressing BCR might be selected through non-CDR-based recognition mechanisms, e.g. through interactions with superantigens, a general feature of BCR expressing IGHV3 subgroup genes [106-109]. From a clinical standpoint, hints suggesting a negative prognostic impact of IGHV3-23 usage in CLL have been reported [110]. Recently, such a suggestion has been confirmed in an Italian multicenter series, but circumscribed to cases expressing mutated IGHV genes [106]. In this series, median TTT of M IGHV3-23 patients were significantly shorter than median TTT of $\mathrm{M}$ non-IGHV3-23 CLL, and IGHV3-23 expression was identified as an independent negative prognosticator in the context of M CLL [106].

\section{ZAP-70}

ZAP-70 encodes for T cell specific zeta-associated protein70 and has been initially identified in T cells as a protein tyrosine kinase that plays a critical role in T-cell-receptor signaling [111]. This molecule is a member of the syk family of tyrosine kinases and is associated with the $\zeta$-chain of the CD3 complex [112].

Gene expression profiling studies in CLL, aimed at identifying differentially expressed genes between UM and M CLL, described ZAP-70 as the most differentially expressed gene between the two CLL subtypes, thus highlighting a high correlation between ZAP-70 expression and IGHV mutational status [63,113]. Consistently, ZAP70 was shown to act as surrogate for IGHV gene mutations when its intra-cytoplasmic expression is investigated by flow cytometry $[5,7,114-116]$, although a common standardized protocol for its detection is still to be defined $[7,114,115,117]$. However, discordance of ZAP-70 expression and IGHV mutational status was reported in about $25 \%$ of cases with a higher number of discordant cases in subgroups with a more aggressive disease such as $11 \mathrm{q}-$ CLL, 17p- CLL or IGHV3-21 CLL (39\%) [118]. Using a cut-off set at $20 \%$ of positive cells, ZAP-70 expression was demonstrated to have a negative prognostic impact in CLL $[5,7]$. The relevance of ZAP-70 as independent prognosticator was provided by multivariate analysis [116].

ZAP-70 can modulate BCR-derived signaling associating with BCR in antigen stimulated CLL cells [119], and can play an indirect role in BCR signal transduction, mainly modulating events at the end of the signaling response [120]. Expression of ZAP-70, which can enhance and prolong on syk and other downstream signaling molecules, can partially determine the different capability of CLL cells to respond to antigenic stimulation [120]. Regarding 
the mechanism(s) underlying the negative prognostic impact of ZAP-70 expression in CLL, it is known that ZAP$70^{+}$CLL cells have a greater capacity to respond to antigeninduced signals through BCR triggering. In particular, ZAP-70 expression and sustained BCR stimuli have been associated with prolonged activation of the Akt and ERK kinases, events which are required for the induction of several antiapoptotic proteins, including Mcl-1, Bcl-xL and XIAP [120-122]. Recently, ZAP-70 expression was demonstrated to mark CLL subsets with enhance capability to respond to chemokine-mediated stimuli (see below).

\section{CD38}

CD38 is a $45-\mathrm{kDa}$ type II membrane glycoprotein first described as an activation antigen whose expression coincided with discrete stages of human $\mathrm{T}$ and $\mathrm{B}$ lymphocyte differentiation [123]. CD38 has been found to be widely expressed in humans within the hematopoietic system (e.g. bone marrow progenitor cells, monocytes, platelets and erytrocytes) and beyond, in brain, prostate, kidney, gut, heart and skeletal muscle [124]. CD38 behaves simultaneously as a cell surface enzyme and as a receptor. As an ectoenzyme, CD38 synthesizes cyclic adenosine diphosphate (ADP) ribose and nicotinic acid adenine dinucleotide phosphate (NAADP), key compounds in the regulation of cytoplasmic $\mathrm{Ca}^{++}$levels [125]. Engagement of CD38 by its ligand CD31 or by specific agonist antibodies induces activation and differentiation signals in $\mathrm{T}$, $B$ and NK cells [126]. Signals mediated by CD38 are tightly regulated by the dynamic localization of the molecule in lipid microdomains within the plasma membrane, and by lateral associations with other proteins or protein complexes [124].

A study by Damle et al. indicated that CD38 expression was heterogeneous among CLL cases [3]. By using a given percentage of CLL cells expressing the antigen $(30 \%$ of positive cells), significant prognostic differences were found by investigating both chemotherapy requirements and overall survival [3]. The same report showed that CLL cells with higher CD38 expression more likely rearranged UM IGHV genes [3]. Thus, CD38 status was proposed as surrogate for IGHV mutation status, although this was not confirmed by subsequent studies, which however substantiated the its independent prognostic significance [12,127-131].

These observations on the prognostic relevance of CD38 found a biologic ground in studies indicating that CLL cell growth and survival were favoured through sequential interactions between CD38 and CD31 and between CD100 and plexin B1, the latter expressed by microenvironmental cells $[132,133]$. These interactions are more likely to occur in peripheral lymphoid organs and/or bone marrow given the higher CD38 expression in residential as opposed to circulating CLL cells [134-136]. Moreover, both bone marrow and peripheral lymphoid organs can provide accessibility to CD31, as endothelial, stromal, and the so-called nurse-like cells all express highCD31 levels [137-139]. Necessary condition for CD38mediated signals are CD38 translocation into lipid rafts and lateral association with CD19, which is also part of the so-called "tetraspan web" (CD19/CD81), and comprises different molecules, including $\beta 1$ integrins such as CD49d [140]. Moreover, CD38+ CLL cells, expecially if coexpressing ZAP-70, are characterized by enhanced migration toward CXCL21/SDF-1 $\alpha$, and CD38 ligation leads to phosphorylation of the activatory tyrosines in ZAP-70 [133,141]. Therefore, ZAP-70 represents a crosspoint molecule where migratory signals mediated via the CXCL21 receptor CXCR4 intersect with growth signals mediated via CD38 [142-144]. Finally, the associated expression of CD38 and CD49d (see below) can provide additional mechanisms explaining the poor prognosis of CD38-expressing CLL.

\section{CD49d}

CD49d, a.k.a. $\alpha 4$ integrin, acts primarily as an adhesion molecule capable of mediating both cell-to-cell interactions, via binding to vascular-cell adhesion molecule-1 (VCAM-1), and interactions with extracellular matrix components by binding to non-RGD sites (a.k.a. CS-1 fragments) of fibronectin (FN), as well as the C1q-like domain of elastin microfibril interfacer-1 (Emilin-1) $[145,146]$. In this regard, CD49d-expressing CLL cells were shown to have a high propensity to adhere to fibronectin substrates, and an increased CD49d protein expression was demonstrated in CLL cells from advanced Rai stage patients [147]. Our group recently collected evidences of VCAM-1 over-expression in the stromalendothelial component found in the context of lymphoid aggregates in bone marrow biopsies (BMB) of CD49d/ CD38-expressing CLL [148]. VCAM-1 upregulation was demonstrated to be due to an overproduction by CD38/ CD49d-expressing CLL cells of specific chemokines (CCL3 and CCL4) upon CD38 triggering, eventually capable to recruit TNF $\alpha$-producing macrophages, which in turn are responsible for VCAM-1 upregulation by stromal/ endothelial cells [148]. VCAM-1/CD49d interactions resulted in an increased survival of CD49d-expressing CLL cells [148]. CD49d-dependent interactions have a role in preventing both spontaneous and drug induced apoptosis of normal or neoplastic B cells [145,149]. Moreover, chemokine-induced transmigration of CLL cells across endothelia depends on CD49d expression by CLL cells and is favoured by the production of the matrix metalloproteinase-9 as the result of CD49d engagement [150]. 
From a clinical point of view, CD49d has been identified as an independent negative prognosticator for CLL, marking a subset of CLL patients characterized by aggressive and accelerated clinical course [8,150-152]. The prognostic relevance of CD49d in CLL may have also therapeutic implications, envisioning the use for CLL patients of Natalizumab (TYSABRI, Biogen Idec, Cambridge, MA and Elan Pharmaceuticals, South San Francisco, CA, USA), a humanized anti-CD49d monoclonal antibody already available and currently employed in autoimmune diseases such as multiple sclerosis and Crohn's disease [153].

\section{Conclusion (see Figure 2)}

B cells carrying BCR with high affinity for autoantigens are usually deleted or addressed towards a secondary rearrangement of heavy/light chains; in the latter case, B cells that reach an "acceptable" ("non-autoreactive") structure are then driven to continue differentiation [154,155]. In some istances, such secondary attempts may fail and B cell clones may retain an "inappropriate" reactivity (autoreactivity, polyreactivity) [156]. As an example, many normal B cell clones with UM IGHV genes produce antibodies capable of a certain degree of polyreactivity by binding multiple antigens (e.g. carbohydrates, nucleic acids, phospholypids). If one of these cells presents or develops primary genetic abnormalities (e.g. 13q14.3 deletions, but also other lesions) it can undergo leukemic transformation. B cells with genetic abnormalities and UM/polyreactive $\mathrm{BCR}$ can increase their number through repeated expositions to antigens (foreign antigens, autoantigens) $[71,157]$. In this regard, immune cross-reactivity between exogenous polysaccharide/carbohydrate antigens and

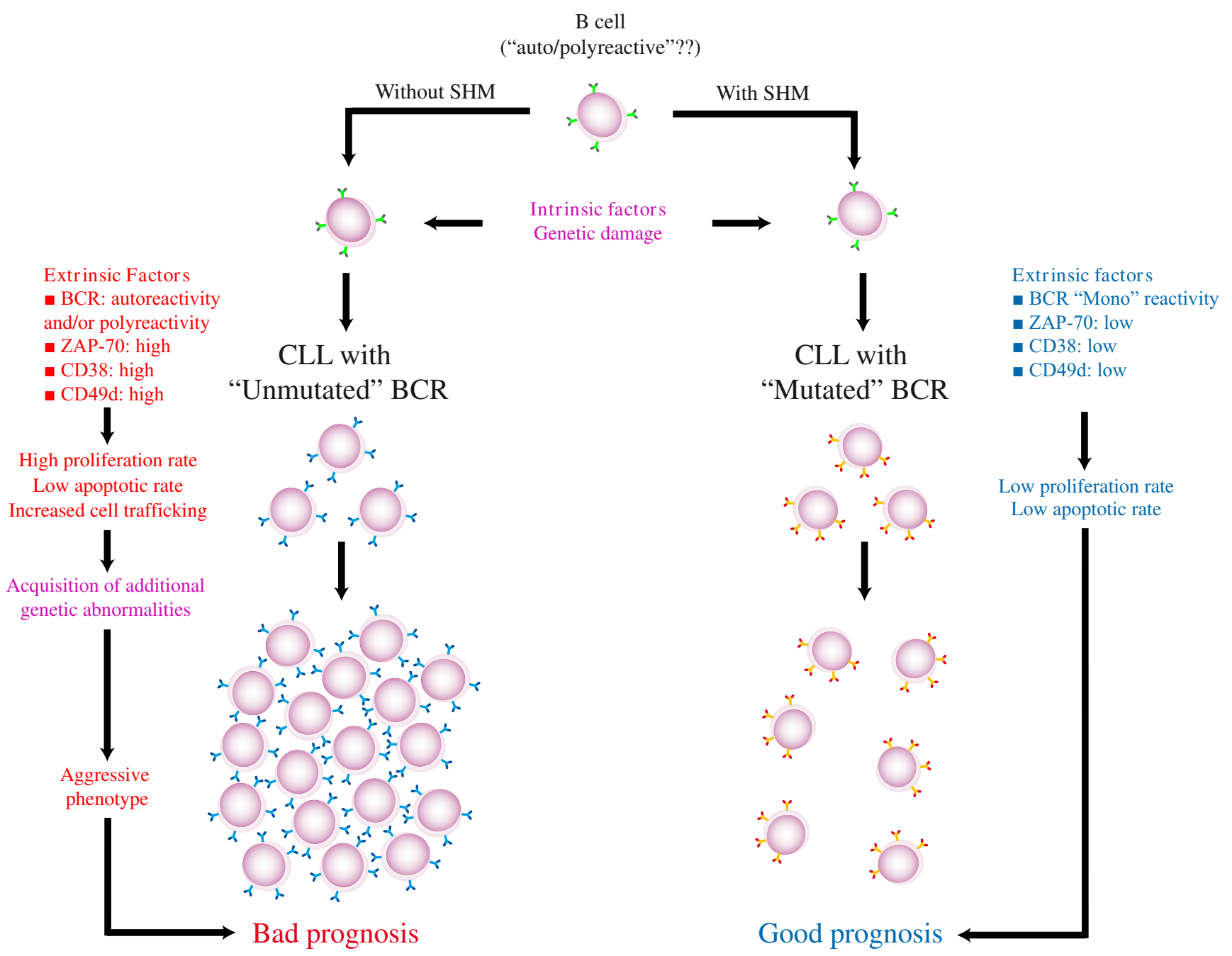

Figure 2

A "multistep" model for CLL origin. 
autoantigens is not infrequent $[158,159]$. Together with BCR, other factors, usually highly expressed in UM CLL, such as ZAP-70, CD38 and CD49d might take part in strengthening the "proliferative" and/or "pro-survival" interactions of CLL cells with microenvironment $[122,133,148,160]$. Such a "proliferative" status also allows CLL cells to acquire additional/secondary genetic changes, transforming them into a more aggressive phenotype [13].

Moreover, the expression of high levels of surface molecules, such as CD38 and CD49d, may facilitate the trafficking of CLL cells in the context of bone marrow and/or lymph nodes where interactions with microenvironmental cells marked by "nurse-like" activities are easier to occur [132,137-139,148]. In this regard, it has been hypothesized that the highest proliferation rate occurs mainly/exclusively in the context of a tiny proportion of tumor cells (i.e. the so-called "tumor initiating cells" a.k.a. "cancer stem cells"), frequently clustered to form sort of pseudofollicolar proliferation centers in lymph nodes and bone marrow [139], but also present in peripheral blood as "circulating cancer stem cells" with features of "side population" in flow cytometry cytograms after fluorescent vital dye staining [161].

Similar mechanism(s) might be hypothesized for M CLL. Also in this case, intrinsic and extrinsic factors may take part in the neoplastic transformation but unlike UM CLL, in M CLL the BCR might be selected by a sole antigen (autoantigen or foreign antigen) or by a group of antigens with very similar characteristics, often with evidence of a geographic-biased distribution [92,105]. This "monoreactivity" might determine a less aggressive pathology $[3,6,77]$. Of note, somatic hypermutation of IGV genes can decrease autoreactivity levels [99]. It is possible to hypothesize that given the less aggressive clinical course, in some cases CLL cells of a mutated clone may be anergic, with an attenuated response to BCR engagement [162164]. The low expression of CD38 and CD49d, usually associated with a M IGHV gene status in CLL, fails to provide additional microenvironmental stimuli.

The hypothesis of a "multistep" origin for CLL is in keeping studies describing the presence of B cells with CLL cell features in about $3.5 \%$ of healthy people, allegedly representing a clonal amplification of a selected set of B lymphocytes $[165,166]$.

\section{Competing interests}

The authors declare that they have no competing interests.

\section{Authors' contributions}

MDB wrote the manuscript, FB, FF, AZ, RB, RM, SD, LL, DGE, GG, GDP contributed to write the manuscript and VG contributed to write and revised the manuscript.

\section{Acknowledgements}

Supported in part by: Ministero della Salute (Ricerca Finalizzata I.R.C.C.S., "Alleanza Contro il Cancro", and Progetto Integrato Oncologia 2006) Rome, Italy; Programmi di Ricerca di Interesse Nazionale (P.R.I.N.) and Fondo per gli Investimenti per la Ricerca di Base (F.I.R.B.), M.U.R., Rome, Italy; Ricerca Scientifica Applicata, Regione Friuli Venezia Giulia, Trieste ("Linfonet"), Italy; Ricerca Sanitaria Finalizzata Regione Piemonte, Torino, Italy; Associazione Italiana contro le Leucemie, linfomi e mielomi (A.I.L.), Venezia Section, Pramaggiore Group, Italy; Novara-A.I.L. Onlus, Novara, Italy; Siena-A.I.L. Onlus, Siena, Italy; Associazione Italiana per la Ricerca sul Cancro (A.I.R.C.), Milan, Italy; Helmut Horten Foundation (Lugano, Switzerland); San Salvatore Foundation (Lugano, Switzerland); Fondazione per la Ricerca e la Cura sui Linfomi (Lugano, Switzerland); The Leukemia \& Lymphoma Society (White Plains, NY).

\section{References}

I. Moreno C, Montserrat E: New prognostic markers in chronic lymphocytic leukemia. Blood Rev 2008, 22:21 I-219.

2. Dohner H, Fischer K, Bentz M, Hansen K, Benner A, Cabot G, Diehl $D$, Schlenk R, Coy J, Stilgenbauer S: $\mathbf{p 5 3}$ gene deletion predicts for poor survival and non-response to therapy with purine analogs in chronic B-cell leukemias. Blood 1995, 85: I580- 1589.

3. Damle RN, Wasil T, Fais F, Ghiotto F, Valetto A, Allen SL, Buchbinder A, Budman D, Dittmar K, Kolitz J, Lichtman SM, Schulman P, Vinciguerra VP, Rai KR, Ferrarini M, Chiorazzi N: Ig V gene mutation status and CD38 expression as novel prognostic indicators in chronic lymphocytic leukemia. Blood 1999, 94: 1840-I847.

4. Dohner H, Stilgenbauer S, Benner A, Leupolt E, Krober A, Bullinger L, Dohner K, Bentz M, Lichter P: Genomic aberrations and survival in chronic lymphocytic leukemia. N Engl J Med 2000, 343:1910-1916.

5. Orchard JA, Ibbotson RE, Davis Z, Wiestner A, Rosenwald A, Thomas PW, Hamblin TJ, Staudt LM, Oscier DG: ZAP-70 expression and prognosis in chronic lymphocytic leukaemia. Lancet 2004, 363:105-III.

6. Degan M, Bomben R, Dal Bo M, Zucchetto A, Nanni P, Rupolo M, Steffan A, Attadia V, Ballerini PF, Damiani D, Pucillo C, Del Poeta G, Colombatti A, Gattei V: Analysis of IgV gene mutations in B cell chronic lymphocytic leukaemia according to antigen-driven selection identifies subgroups with different prognosis and usage of the canonical somatic hypermutation machinery. $\mathrm{Br}$ J Haematol 2004, I 26:29-42.

7. Rassenti LZ, Huynh L, Toy TL, Chen L, Keating MJ, Gribben JG, Neuberg DS, Flinn IW, Rai KR, Byrd JC, Kay NE, Greaves A, Weiss A Kipps TJ: ZAP-70 compared with immunoglobulin heavychain gene mutation status as a predictor of disease progression in chronic lymphocytic leukemia. N Engl J Med 2004, 35 I:893-90I.

8. Gattei V, Bulian P, Del Principe MI, Zucchetto A, Maurillo L, Buccisano F, Bomben R, Dal-Bo M, Luciano F, Rossi FM, Degan M, Amadori S, Del PG: Relevance of CD49d protein expression as overall survival and progressive disease prognosticator in chronic lymphocytic leukemia. Blood 2008, I I I:865-873.

9. Mayr C, Speicher MR, Kofler DM, Buhmann R, Strehl J, Busch R, Hallek M, Wendtner CM: Chromosomal translocations are associated with poor prognosis in chronic lymphocytic leukemia. Blood 2006, 107:742-751.

10. Haferlach C, Dicker F, Schnittger S, Kern W, Haferlach T: Comprehensive genetic characterization of CLL: a study on 506 cases analysed with chromosome banding analysis, interphase FISH, $\operatorname{lgV}(\mathbf{H})$ status and immunophenotyping. Leukemia 2007, 21:2442-245I.

II. Pfeifer D, Pantic M, Skatulla I, Rawluk J, Kreutz C, Martens UM, Fisch P, Timmer J, Veelken H: Genome-wide analysis of DNA copy number changes and LOH in CLL using high-density SNP arrays. Blood 2007, 109:1202-1210.

12. Krober A, Seiler T, Benner A, Bullinger L, Bruckle E, Lichter P, Dohner $\mathrm{H}$, Stilgenbauer S: V(H) mutation status, CD38 expression level, genomic aberrations, and survival in chronic lymphocytic leukemia. Blood 2002, 100:1410-1416.

13. Chiorazzi N, Rai KR, Ferrarini M: Chronic Lymphocytic Leukemia. N Engl J Med 2005, 352:804-8I 5. 
14. Nicoloso MS, Kipps TJ, Croce CM, Calin GA: MicroRNAs in the pathogeny of chronic lymphocytic leukaemia. $\mathrm{Br} J$ Haematol 2007, I39:709-716.

15. Calin GA, Dumitru CD, Shimizu M, Bichi R, Zupo S, Noch E, Aldler $H$, Rattan S, Keating M, Rai K, Rassenti L, Kipps T, Negrini M, Bullrich $F$, Croce CM: Frequent deletions and down-regulation of micro- RNA genes miRI5 and miRI6 at I3ql4 in chronic lymphocytic leukemia. Proc Natl Acad Sci USA 2002, 99:I5524-I5529.

16. Ouillette P, Erba H, Kujawski L, Kaminski M, Shedden K, Malek SN: Integrated genomic profiling of chronic lymphocytic leukemia identifies subtypes of deletion I3qI4. Cancer Res 2008 , 68: $1012-1021$.

17. Valencia-Sanchez MA, Liu J, Hannon GJ, Parker R: Control of translation and mRNA degradation by miRNAs and siRNAs. Genes Dev 2006, 20:515-524.

18. Cimmino A, Calin GA, Fabbri M, lorio MV, Ferracin M, Shimizu M, Wojcik SE, Aqeilan RI, Zupo S, Dono M, Rassenti L, Alder H, Volinia S, Liu CG, Kipps TJ, Negrini M, Croce CM: miR-I5 and miR-I6 induce apoptosis by targeting BCL2. Proc Natl Acad Sci USA 2005, 1 02:13944-13949.

19. Fulci V, Chiaretti S, Goldoni M, Azzalin G, Carucci N, Tavolaro S, Castellano L, Magrelli A, Citarella F, Messina M, Maggio R, Peragine N, Santangelo S, Mauro FR, Landgraf P, Tuschl T, Weir DB, Chien M, Russo J], Ju J, Sheridan R, Sander C, Zavolan M, Guarini A, Foa R, Macino G: Quantitative technologies establish a novel microRNA profile of chronic lymphocytic leukemia. Blood 2007, 109:4944-495I.

20. Calin GA, Cimmino A, Fabbri M, Ferracin M, Wojcik SE, Shimizu M, Taccioli C, Zanesi N, Garzon R, Aqeilan RI, Alder H, Volinia S, Rassenti L, Liu X, Liu CG, Kipps TJ, Negrini M, Croce CM: MiR-I 5a and miR-I 6-I cluster functions in human leukemia. Proc Natl Acad Sci USA 2008, I 05:5166-5I7I.

21. Buhl AM, Jurlander J, Jorgensen FS, Ottesen AM, Cowland JB, Gjerdrum LM, Hansen BV, Leffers H: Identification of a gene on chromosome I2q22 uniquely overexpressed in chronic Iymphocytic leukemia. Blood 2006, I 07:2904-29 I I.

22. Buhl AM, Novotny GW, Josefsson P, Nielsen JE, Pedersen LB, Geisler C, Rassenti LZ, Kipps T], Jurlander J, Leffers H: The CLLUI expression level is a stable and inherent feature of the chronic lymphocytic leukemia clone. Leukemia 2009, 23(6): I I82-6.

23. Josefsson $\mathrm{P}$, Geisler $\mathrm{CH}$, Leffers $\mathrm{H}$, Petersen JH, Andersen MK, Jurlander J, Buhl AM: CLLUI expression analysis adds prognostic information to risk prediction in chronic lymphocytic leukemia. Blood 2007, 109:4973-4979.

24. Austen B, Powell JE, Alvi A, Edwards I, Hooper L, Starczynski J, Taylor AM, Fegan C, Moss P, Stankovic T: Mutations in the ATM gene lead to impaired overall and treatment-free survival that is independent of IGVH mutation status in patients with BCLL. Blood 2005, I 06:3175-3182.

25. Oscier DG, Gardiner AC, Mould SJ, Glide S, Davis ZA, Ibbotson RE, Corcoran MM, Chapman RM, Thomas PW, Copplestone JA, Orchard JA, Hamblin T]: Multivariate analysis of prognostic factors in CLL: clinical stage, IGVH gene mutational status, and loss or mutation of the p53 gene are independent prognostic factors. Blood 2002, 100:1 177-1 184.

26. Byrd JC, Gribben JG, Peterson BL, Grever MR, Lozanski G, Lucas DM, Lampson B, Larson RA, Caligiuri MA, Heerema NA: Select high-risk genetic features predict earlier progression following chemoimmunotherapy with fludarabine and rituximab in chronic lymphocytic leukemia: justification for risk-adapted therapy. J Clin Oncol 2006, 24:437-443.

27. Krober A, Bloehdorn J, Hafner S, Buhler A, Seiler T, Kienle D, Winkler D, Bangerter M, Schlenk RF, Benner A, Lichter P, Dohner H, Stilgenbauer S: Additional genetic high-risk features such as I I q deletion, I7p deletion, and V3-2I usage characterize discordance of ZAP-70 and VH mutation status in chronic lymphocytic leukemia. J Clin Oncol 2006, 24:969-975.

28. Austen B, Skowronska A, Baker C, Powell JE, Gardiner A, Oscier D, Majid A, Dyer M, Siebert R, Taylor AM, Moss PA, Stankovic T: Mutation status of the residual ATM allele is an important determinant of the cellular response to chemotherapy and survival in patients with chronic lymphocytic leukemia containing an I I q deletion. J Clin Oncol 2007, 25:5448-5457.

29. Kalla C, Scheuermann MO, Kube I, Schlotter M, Mertens D, Dohner $\mathrm{H}$, Stilgenbauer S, Lichter P: Analysis of I I q22-q23 deletion tar- get genes in B-cell chronic lymphocytic leukaemia: evidence for a pathogenic role of NPAT, CUL5, and PPP2RIB. Eur J Cancer 2007, 43: I328-1335.

30. Seiler T, Dohner H, Stilgenbauer S: Risk stratification in chronic lymphocytic leukemia. Semin Oncol 2006, 33:186-194.

31. Harris SL, Levine AJ: The $\mathbf{p 5 3}$ pathway: positive and negative feedback loops. Oncogene 2005, 24:2899-2908.

32. Vassilev LT, Vu BT, Graves B, Carvajal D, Podlaski F, Filipovic Z, Kong N, Kammlott U, Lukacs C, Klein C, Fotouhi N, Liu EA: In vivo activation of the p53 pathway by small-molecule antagonists of MDM2. Science 2004, 303:844-848.

33. Michael D, Oren $\mathrm{M}$ : The $\mathbf{p 5 3}$ and $\mathbf{M d m} \mathbf{2}$ families in cancer. Curr Opin Genet Dev 2002, I 2:53-59.

34. Michael D, Oren $M$ : The p53-Mdm2 module and the ubiquitin system. Semin Cancer Biol 2003, I 3:49-58.

35. Vassilev LT: MDM2 inhibitors for cancer therapy. Trends $\mathrm{Mol}$ Med 2007, | 3:23-31.

36. Stommel JM, Wahl GM: Accelerated MDM2 auto-degradation induced by DNA-damage kinases is required for p53 activation. EMBO J 2004, 23: I547-I556.

37. Secchiero $P$, Barbarotto $E$, Tiribelli $M$, Zerbinati $C$, di lasio $M G$, Gonelli A, Cavazzini F, Campioni D, Fanin R, Cuneo A, Zauli G: Functional integrity of the p53-mediated apoptotic pathway induced by the nongenotoxic agent nutlin-3 in B-cell chronic lymphocytic leukemia (B-CLL). Blood 2006, I 07:4I 22-4I 29.

38. Shanafelt TD, Witzig TE, Fink SR, Jenkins RB, Paternoster SF, Smoley SA, Stockero KJ, Nast DM, Flynn HC, Tschumper RC, Geyer S, Zent CS, Call TG, Jelinek DF, Kay NE, Dewald GW: Prospective evaluation of clonal evolution during long-term follow-up of patients with untreated early-stage chronic lymphocytic leukemia. I Clin Oncol 2006, 24:4634-464 I .

39. Stilgenbauer S, Sander S, Bullinger L, Benner A, Leupolt E, Winkler D, Krober $A$, Kienle $D$, Lichter $P$, Dohner $H$ : Clonal evolution in chronic lymphocytic leukemia: acquisition of high-risk genomic aberrations associated with unmutated $\mathrm{VH}$, resistance to therapy, and short survival. Haematologica 2007, 92: I 242- 1245 .

40. Shanafelt TD, Hanson C, Dewald GW, Witzig TE, Laplant B, Abrahamzon J, Jelinek DF, Kay NE: Karyotype evolution on fluorescent in situ hybridization analysis is associated with short survival in patients with chronic lymphocytic leukemia and is related to CD49d expression. I Clin Oncol 2008, 26:e5-e6.

4I. Lozanski G, Heerema NA, Flinn IW, Smith L, Harbison J, Webb J, Moran M, Lucas M, Lin T, Hackbarth ML, Proffitt JH, Lucas D, Grever $M R$, Byrd JC: Alemtuzumab is an effective therapy for chronic lymphocytic leukemia with p53 mutations and deletions. Blood 2004, 103:3278-3281.

42. Rossi D, Cerri M, Deambrogi C, Sozzi E, Cresta S, Rasi S, De PL, Spina V, Gattei V, Capello D, Forconi F, Lauria F, Gaidano G: The prognostic value of TP53 mutations in chronic lymphocytic leukemia is independent of Dell 7p/3: implications for overall survival and chemorefractoriness. Clin Cancer Res 2009, 15:995-1004.

43. Pettitt AR, Sherrington PD, Stewart G, Cawley JC, Taylor AM, Stankovic T: p53 dysfunction in B-cell chronic lymphocytic leukemia: inactivation of ATM as an alternative to TP53 mutation. Blood 2001, 98:814-822.

44. Valganon $M$, Giraldo P, Agirre $X$, Larrayoz MJ, Rubio-Martinez A, Rubio-Felix D, Calasanz MJ, Odero MD: p53 Aberrations do not predict individual response to fludarabine in patients with $B$ cell chronic lymphocytic leukaemia in advanced stages Rai III/IV. Br J Haematol 2005, I 29:53-59.

45. Sturm I, Bosanquet AG, Hummel M, Dorken B, Daniel PT: In B-CLL, the codon 72 polymorphic variants of $\mathrm{p53}$ are not related to drug resistance and disease prognosis. BMC Cancer 2005, 5: 105.

46. Gryshchenko I, Hofbauer S, Stoecher M, Daniel PT, Steurer M, Gaiger A, Eigenberger K, Greil R, Tinhofer I: MDM2 SNP309 is associated with poor outcome in B-cell chronic lymphocytic leukemia. J Clin Oncol 2008, 26:2252-2257.

47. Dighiero G, Hamblin T]: Chronic lymphocytic leukaemia. Lancet 2008, 371:1017-1029.

48. Grever MR, Lucas DM, Johnson AJ, Byrd JC: Novel agents and strategies for treatment of p53-defective chronic lymphocytic leukemia. Best Pract Res Clin Haematol 2007, 20:545-556. 
49. Zenz T, Dohner H, Stilgenbauer S: Genetics and risk-stratified approach to therapy in chronic lymphocytic leukemia. Best Pract Res Clin Haematol 2007, 20:439-453.

50. Dicker F, Schnittger S, Haferlach T, Kern W, Schoch C: Immunostimulatory oligonucleotide-induced metaphase cytogenetics detect chromosomal aberrations in $80 \%$ of CLL patients: A study of I32 CLL cases with correlation to FISH, IgVH status, and CD38 expression. Blood 2006, 108:3152-3160.

5I. Bentz M, Huck K, du MS, Joos S, Werner CA, Fischer K, Dohner H, Lichter P: Comparative genomic hybridization in chronic Bcell leukemias shows a high incidence of chromosomal gains and losses. Blood 1995, 85:3610-3618.

52. Novak U, Oppliger LE, Hager J, Muhlematter D, Jotterand M, Besse C, Leupin N, Ratschiller D, Papp J, Kearsey G, Aebi S, Graber H, Jaggi R, Luthi JM, Meyer-Monard S, Lathrop M, Tobler A, Fey MF: A highresolution allelotype of $B$-cell chronic lymphocytic leukemia (B-CLL). Blood 2002, 100:1787-1794.

53. Ottaggio L, Viaggi S, Zunino A, Zupo S, Rossi E, Spriano M, Abbondandolo A, Ferrarini M: Chromosome aberrations evaluated by comparative genomic hybridization in B-cell chronic lymphocytic leukemia: correlation with CD38 expression. Haematologica 2003, 88:769-777.

54. Forconi F, Rinaldi A, Kwee I, Sozzi E, Raspadori D, Rancoita PM, Scandurra M, Rossi D, Deambrogi C, Capello D, Zucca E, Marconi D, Bomben R, Gattei V, Lauria F, Gaidano G, Bertoni F: Genome-wide DNA analysis identifies recurrent imbalances predicting outcome in chronic lymphocytic leukaemia with $17 p$ deletion. $\mathrm{Br}$ J Haematol 2008, 143:532-536.

55. Bechter OE, Eisterer W, Pall G, Hilbe W, Kuhr T, Thaler J: Telomere length and telomerase activity predict survival in patients with B cell chronic lymphocytic leukemia. Cancer Res 1998, 58:49|8-4922.

56. Damle RN, Batliwalla FM, Ghiotto F, Valetto A, Albesiano E, Sison C, Allen SL, Kolitz J, Vinciguerra VP, Kudalkar P, Wasil T, Rai KR, Ferrarini M, Gregersen PK, Chiorazzi N: Telomere length and telomerase activity delineate distinctive replicative features of the B-CLL subgroups defined by immunoglobulin $V$ gene mutations. Blood 2004, 103:375-382.

57. Grabowski P, Hultdin M, Karlsson K, Tobin G, Aleskog A, Thunberg $U$, Laurell A, Sundstrom C, Rosenquist R, Roos G: Telomere length as a prognostic parameter in chronic lymphocytic leukemia with special reference to $\mathrm{VH}$ gene mutation status. Blood 2005, 105:4807-48/2

58. Roos G, Krober A, Grabowski P, Kienle D, Buhler A, Dohner H, Rosenquist R, Stilgenbauer S: Short telomeres are associated with genetic complexity, high-risk genomic aberrations, and short survival in chronic lymphocytic leukemia. Blood 2008, I I I:2246-2252.

59. Terrin L, Trentin L, Degan M, Corradini I, Bertorelle R, Carli P, Maschio N, Bo MD, Noventa F, Gattei V, Semenzato G, De RA: Telomerase expression in B-cell chronic lymphocytic leukemia predicts survival and delineates subgroups of patients with the same igVH mutation status and different outcome. Leukemia 2007, 21:965-972.

60. Weng NP, Granger L, Hodes RJ: Telomere lengthening and telomerase activation during human $B$ cell differentiation. Proc Natl Acad Sci USA 1997, 94:10827-10832.

61. Ladetto M, Compagno M, Ricca I, Pagano M, Rocci A, Astolfi M, Drandi D, di Celle PF, Dell'Aquila M, Mantoan B, Vallet S, Pagliano G, De MF, Francese R, Santo L, Cuttica A, Marinone C, Boccadoro M, Tarella C: Telomere length correlates with histopathogenesis according to the germinal center in mature B-cell lymphoproliferative disorders. Blood 2004, 103:4644-4649.

62. Klein U, Tu Y, Stolovitzky GA, Mattioli M, Cattoretti G, Husson $H$, Freedman A, Inghirami G, Cro L, Baldini L, Neri A, Califano A, DallaFavera R: Gene expression profiling of B cell chronic lymphocytic leukemia reveals a homogeneous phenotype related to memory B cells. J Exp Med 200I, 194:1625-1638.

63. Rosenwald A, Alizadeh AA, Widhopf G, Simon R, Davis RE, Yu X, Yang L, Pickeral OK, Rassenti LZ, Powell J, Botstein D, Byrd JC, Grever MR, Cheson BD, Chiorazzi N, Wilson WH, Kipps TJ, Brown PO, Staudt LM: Relation of gene expression phenotype to immunoglobulin mutation genotype in B cell chronic lymphocytic leukemia. J Exp Med 200I, 194:1639-1647.
64. Klein U, la-Favera R: New insights into the phenotype and cell derivation of B cell chronic lymphocytic leukemia. Curr Top Microbiol Immunol 2005, 294:3 I-49.

65. Caligaris-Cappio F, Ghia P: The normal counterpart to the chronic lymphocytic leukemia B cell. Best Pract Res Clin Haematol 2007, 20:385-397.

66. Odegard VH, Schatz DG: Targeting of somatic hypermutation. Nat Rev Immunol 2006, 6:573-583.

67. Moreau EJ, Matutes E, A'Hern RP, Morilla AM, Morilla RM, OwusuAnkomah KA, Seon BK, Catovsky D: Improvement of the chronic lymphocytic leukemia scoring system with the monoclonal antibody SN8 (CD79b). Am J Clin Pathol 1997, 108:378-382.

68. Potter KN, Mockridge Cl, Neville L, Wheatley I, Schenk M, Orchard J, Duncombe AS, Packham G, Stevenson FK: Structural and functional features of the B-cell receptor in IgG-positive chronic lymphocytic leukemia. Clin Cancer Res 2006, I 2: 1672-1679.

69. Schroeder HW Jr, Dighiero G: The pathogenesis of chronic lymphocytic leukemia: analysis of the antibody repertoire. Immunol Today 1994, 15:288-294.

70. Oscier DG, Thompsett A, Zhu D, Stevenson FK: Differential rates of somatic hypermutation in $\mathbf{V}(\mathrm{H})$ genes among subsets of chronic lymphocytic leukemia defined by chromosomal abnormalities. Blood 1997, 89:4153-4160.

7I. Fais F, Ghiotto F, Hashimoto S, Sellars B, Valetto A, Allen SL, Schulman P, Vinciguerra VP, Rai K, Rassenti LZ, Kipps TJ, Dighiero G, Schroeder HW Jr, Ferrarini M, Chiorazzi N: Chronic lymphocytic leukemia $B$ cells express restricted sets of mutated and unmutated antigen receptors. J Clin Invest 1998, 102: I5 I5- I 525.

72. Chang $B$, Casali $P$ : The CDRI sequences of a major proportion of human germline Ig $\mathrm{VH}$ genes are inherently susceptible to amino acid replacement. Immunol Today 1994, I 5:367-373.

73. Chang B, Casali P: A sequence analysis of human germline Ig VH and VL genes. The CDR Is of a major proportion of $V H$, but not VL, genes display a high inherent susceptibility to amino acid replacement. Ann N Y Acad Sci 1995, 764: I70- I79.

74. Lossos IS, Tibshirani R, Narasimhan B, Levy R: The inference of antigen selection on Ig genes. J Immunol 2000, 165:5 I22-5I 26.

75. Keating MJ, Chiorazzi N, Messmer B, Damle RN, Allen SL, Rai KR, Ferrarini M, Kipps TJ: Biology and treatment of chronic lymphocytic leukemia. Hematology (Am.Soc Hematol.Educ Program) 2003:153-175.

76. Bomben R, Dal Bo M, Zucchetto A, Zaina E, Nanni P, Sonego P, Del Poeta G, Degan M, Gattei V: Mutational status of $\operatorname{IgV}(\mathbf{H})$ genes in B-cell chronic lymphocytic leukemia and prognosis: percent mutations or antigen-driven selection? Leukemia 2005 , 19:1490-1492.

77. Hamblin TJ, Davis Z, Gardiner A, Oscier DG, Stevenson FK: Unmutated $\lg \mathbf{V}(\mathbf{H})$ genes are associated with a more aggressive form of chronic lymphocytic leukemia. Blood 1999, 94:1848-1854.

78. Dreger P, Stilgenbauer S, Benner A, Ritgen M, Krober A, Kneba M, Schmitz N, Dohner $H$ : The prognostic impact of autologous stem cell transplantation in patients with chronic lymphocytic leukemia: a risk-matched analysis based on the VH gene mutational status. Blood 2004, 103:2850-2858.

79. Muramatsu M, Kinoshita K, Fagarasan S, Yamada S, Shinkai Y, Honjo $\mathrm{T}$ : Class switch recombination and hypermutation require activation-induced cytidine deaminase (AID), a potential RNA editing enzyme. Cell 2000, 102:553-563.

80. Pasqualucci L, Guglielmino R, Houldsworth J, Mohr J, Aoufouchi S, Polakiewicz R, Chaganti RS, la-Favera R: Expression of the AID protein in normal and neoplastic B cells. Blood 2004, 104:3318-3325.

8I. Albesiano E, Messmer BT, Damle RN, Allen SL, Rai KR, Chiorazzi N: Activation-induced cytidine deaminase in chronic lymphocytic leukemia B cells: expression as multiple forms in a dynamic, variably sized fraction of the clone. Blood 2003, 1 02:3333-3339.

82. Cerutti A, Zan H, Kim EC, Shah S, Schattner EJ, Schaffer A, Casali P: Ongoing in vivo immunoglobulin class switch DNA recombination in chronic lymphocytic leukemia B cells. J Immunol 2002, 169:6594-6603.

83. Oppezzo P, Vuillier F, Vasconcelos Y, Dumas G, Magnac C, PayelleBrogard B, Pritsch O, Dighiero G: Chronic lymphocytic leukemia B cells expressing AID display dissociation between class 
switch recombination and somatic hypermutation. Blood 2003, 1 $01: 4029-4032$

84. Sahota SS, Davis Z, Hamblin TJ, Stevenson FK: Somatic mutation of bcl-6 genes can occur in the absence of $\mathrm{V}(\mathrm{H})$ mutations in chronic lymphocytic leukemia. Blood 2000, 95:3534-3540.

85. Reiniger L, Bodor C, Bognar A, Balogh Z, Csomor J, Szepesi A, Kopper L, Matolcsy A: Richter's and prolymphocytic transformation of chronic lymphocytic leukemia are associated with high mRNA expression of activation-induced cytidine deaminase and aberrant somatic hypermutation. Leukemia 2006, 20:1089-1095.

86. Heintel D, Kroemer E, Kienle D, Schwarzinger I, Gleiss A, Schwarzmeier J, Marculescu R, Le T, Mannhalter C, Gaiger A, Stilgenbauer S, Dohner $\mathrm{H}$, Fonatsch $\mathrm{C}$, Jager U: High expression of activationinduced cytidine deaminase (AID) mRNA is associated with unmutated IGVH gene status and unfavourable cytogenetic aberrations in patients with chronic lymphocytic leukaemia. Leukemia 2004, 18:756-762.

87. Messmer BT, Albesiano E, Messmer D, Chiorazzi N: The pattern and distribution of immunoglobulin VH gene mutations in chronic lymphocytic leukemia B cells are consistent with the canonical somatic hypermutation process. Blood 2004, 103:3490-3495.

88. Ghia P, Stamatopoulos K, Belessi C, Moreno C, Stella S, Guida G, Michel A, Crespo M, Laoutaris N, Montserrat E, Anagnostopoulos A, Dighiero G, Fassas A, Caligaris-Cappio F, Davi F: Geographic patterns and pathogenetic implications of IGHV gene usage in chronic lymphocytic leukemia: the lesson of the IGHV3-2I gene. Blood 2005, 105:1678-1685.

89. Stamatopoulos K, Belessi C, Moreno C, Boudjograh M, Guida G, Smilevska T, Belhoul L, Stella S, Stavroyianni N, Crespo M, Hadzidimitriou A, Sutton L, Bosch F, Laoutaris N, Anagnostopoulos A, Montserrat E, Fassas A, Dighiero G, Caligaris-Cappio F, Merle-Beral H, Ghia P, Davi F: Over $\mathbf{2 0} \%$ of patients with chronic lymphocytic leukemia carry stereotyped receptors: Pathogenetic implications and clinical correlations. Blood 2007, 109:259-270.

90. Bomben R, Dal Bo M, Capello D, Benedetti D, Marconi D, Zucchetto A, Forconi F, Maffei R, Ghia EM, Laurenti L, Bulian P, Del Principe MI, Palermo G, Thorselius M, Degan M, Campanini R, Guarini A, Del Poeta G, Rosenquist R, Efremov DG, Marasca R, Foa R, Gaidano G, Gattei V: Comprehensive characterization of IGHV3-2Iexpressing B-cell chronic lymphocytic leukemia: an Italian multicenter study. Blood 2007, 109:2989-2998.

91. Murray F, Darzentas N, Hadzidimitriou A, Tobin G, Boudjogra M, Scielzo C, Laoutaris N, Karlsson K, Baran-Marzsak F, Tsaftaris A, Moreno C, Anagnostopoulos A, Caligaris-Cappio F, Vaur D, Ouzounis C, Belessi C, Ghia P, Davi F, Rosenquist R, Stamatopoulos $\mathrm{K}$ : Stereotyped patterns of somatic hypermutation in subsets of patients with chronic lymphocytic leukemia: implications for the role of antigen selection in leukemogenesis. Blood 2008, III: I524-1533.

92. Bomben R, Dal BM, Capello D, Forconi F, Maffei R, Laurenti L, Rossi D, Del Principe MI, Zucchetto A, Bertoni F, Rossi FM, Bulian P, Cattarossi I, llariucci F, Sozzi E, Spina V, Zucca E, Degan M, Lauria F, Del PG, Efremov DG, Marasca R, Gaidano G, Gattei V: Molecular and clinical features of chronic lymphocytic leukaemia with stereotyped B cell receptors: results from an Italian multicentre study. Br J Haematol 2009, I 44:492-506.

93. Tobin G, Thunberg U, Karlsson K, Murray F, Laurell A, Willander K, Enblad G, Merup M, Vilpo J, Juliusson G, Sundstrom C, Soderberg O, Roos G, Rosenquist R: Subsets with restricted immunoglobulin gene rearrangement features indicate a role for antigen selection in the development of chronic lymphocytic leukemia. Blood 2004, 104:2879-2885.

94. Messmer BT, Albesiano E, Efremov DG, Ghiotto F, Allen SL, Kolitz J, Foa R, Damle RN, Fais F, Messmer D, Rai KR, Ferrarini M, Chiorazzi $\mathrm{N}$ : Multiple distinct sets of stereotyped antigen receptors indicate a role for antigen in promoting chronic lymphocytic leukemia. J Exp Med 2004, 200:519-525.

95. Widhopf GF II, Rassenti LZ, Toy TL, Gribben JG, Wierda WG, Kipps $\mathrm{TJ}$ : Chronic lymphocytic leukemia B cells of more than $\mathbf{I} \%$ of patients express virtually identical immunoglobulins. Blood 2004, 104:2499-2504.

96. Widhopf GF, Goldberg CJ, Toy TL, Rassenti LZ, Wierda WG, Byrd JC, Keating MJ, Gribben JG, Rai KR, Kipps TJ: Nonstochastic pairing of immunoglobulin heavy and light chains expressed by chronic lymphocytic leukemia B cells is predicated on the heavy chain CDR3. Blood 2008, I I I:3 I37-3 I44.

97. Messmer BT, Raphael BJ, Aerni SJ, Widhopf GF, Rassenti LZ, Gribben JG, Kay NE, Kipps TJ: Computational identification of CDR3 sequence archetypes among immunoglobulin sequences in chronic lymphocytic leukemia. Leuk Res 2009, 33:368-376.

98. Lanemo MA, Hellqvist E, Sidorova E, Soderberg A, Baxendale H, Dahle C, Willander K, Tobin G, Backman E, Soderberg O, Rosenquist $R$, Horkko S, Rosen A: A new perspective: molecular motifs on oxidized LDL, apoptotic cells, and bacteria are targets for chronic lymphocytic leukemia antibodies. Blood 2008, I I I:3838-3848.

99. Herve M, Xu K, Ng YS, Wardemann H, Albesiano E, Messmer BT, Chiorazzi N, Meffre E: Unmutated and mutated chronic lymphocytic leukemias derive from self-reactive B cell precursors despite expressing different antibody reactivity. J Clin Invest 2005, II 5: 1636-1643.

100. Ghiotto F, Fais F, Valetto A, Albesiano E, Hashimoto S, Dono M, lkematsu H, Allen SL, Kolitz J, Rai KR, Nardini M, Tramontano A, Ferrarini $M$, Chiorazzi $N$ : Remarkably similar antigen receptors among a subset of patients with chronic lymphocytic leukemia. J Clin Invest 2004, I I 3:1008-1016.

101. Athanasiadou A, Stamatopoulos K, Gaitatzi M, Stavroyianni N, Fassas A, Anagnostopoulos A: Recurrent cytogenetic findings in subsets of patients with chronic lymphocytic leukemia expressing IgG-switched stereotyped immunoglobulins. Haematologica 2008, 93:473-474.

102. Rossi D, Cerri M, Capello D, Deambrogi C, Rossi FM, Zucchetto A, De PL, Cresta S, Rasi S, Spina V, Franceschetti S, Lunghi M, Vendramin C, Bomben R, Ramponi A, Monga G, Conconi A, Magnani C, Gattei $\mathrm{V}$, Gaidano G: Biological and clinical risk factors of chronic lymphocytic leukaemia transformation to Richter syndrome. Br J Haematol 2008 in press.

103. Rossi D, Spina V, Cerri M, Rasi S, Deambrogi C, De PL, Laurenti L, Maffei R, Forconi F, Bertoni F, Zucca E, Agostinelli C, Cabras A, Lucioni M, Martini M, Magni M, Deaglio S, Ladetto M, Nomdedeu JF, Besson C, Ramponi A, Canzonieri V, Paulli M, Marasca R, Larocca LM, Carbone A, Pileri SA, Gattei V, Gaidano G: Stereotyped B-Cell Receptor Is an Independent Risk Factor of Chronic Lymphocytic Leukemia Transformation to Richter Syndrome. Clin Cancer Res 2009, I 5( I 3):44 I 5-22. Epub 2009 Jun 9

104. Tobin G, Thunberg U, Johnson A, Eriksson I, Soderberg O, Karlsson K, Merup M, Juliusson G, Vilpo J, Enblad G, Sundstrom C, Roos G, Rosenquist R: Chronic lymphocytic leukemias utilizing the VH3-2I gene display highly restricted Vlambda2-I 4 gene use and homologous CDR3s: implicating recognition of a common antigen epitope. Blood 2003, I 0 I:4952-4957.

105. Thorselius M, Krober A, Murray F, Thunberg U, Tobin G, Buhler A Kienle D, Albesiano E, Maffei R, Dao-Ung LP, Wiley J, Vilpo J, Laurell A, Merup M, Roos G, Karlsson K, Chiorazzi N, Marasca R, Dohner H, Stilgenbauer S, Rosenquist R: Strikingly homologous immunoglobulin gene rearrangements and poor outcome in $\mathrm{VH} 3$ 2 I-using chronic lymphocytic leukemia patients independent of geographic origin and mutational status. Blood 2006, 107:2889-2894.

106. Bomben R, Dal Bo M, Benedetti D, Capello D, Forconi F, Maffei R, Laurenti L, Marconi D, Rossi D, Bertoni F, Del Principe MI, Luciano F, Sozzi E, Zucchetto A, Rossi FM, Bulian P, Zucca E, Degan M, Efremov DG, Marasca R, Del Poeta G, Gaidano G, Gattei V: Expression of mutated IGHV3-23 genes has independent prognostic relevance in chronic lymphocytic leukemia and identifies a disease subset with peculiar molecular and biological features. Haematologica 2009, 94(s2): 141. (Abstract)

107. Hillson JL, Karr NS, Oppliger IR, Mannik M, Sasso EH: The structural basis of germline-encoded VH3 immunoglobulin binding to staphylococcal protein A. J Exp Med 1993, I I8:331-336.

108. Silverman G], Goodyear CS: A model B-cell superantigen and the immunobiology of B lymphocytes. Clin Immunol 2002, 102:117-134.

109. Silverman G], Goodyear CS: Confounding B-cell defences: lessons from a staphylococcal superantigen. Nat Rev Immunol 2006, 6:465-475.

1 10. Krober A, Benner A, Buhler A, Dohner H, Stilgenbauer S: Multivariate Survival Analysis of Specific VH-Genes in CLL: V3-2I and V3-23 Are Prognostic Factors Indipendently of the VH Mutation Status. Blood 2002, 100:196a-197a. (Abstract) 
1II. Chu DH, Morita CT, Weiss A: The Syk family of protein tyrosine kinases in T-cell activation and development. Immunol Rev 1998, 165:167-180.

I 12. Chan AC, van Oers NS, Tran A, Turka L, Law CL, Ryan JC, Clark EA, Weiss A: Differential expression of ZAP-70 and Syk protein tyrosine kinases, and the role of this family of protein tyrosine kinases in TCR signaling. J Immunol 1994, I52:4758-4766.

1 13. Wiestner A, Rosenwald A, Barry TS, Wright G, Davis RE, Henrickson SE, Zhao H, Ibbotson RE, Orchard JA, Davis Z, Stetler-Stevenson M, Raffeld M, Arthur DC, Marti GE, Wilson WH, Hamblin TJ, Oscier DG, Staudt LM: ZAP-70 expression identifies a chronic lymphocytic leukemia subtype with unmutated immunoglobulin genes, inferior clinical outcome, and distinct gene expression profile. Blood 2003, 101:4944-4951.

114. Crespo M, Bosch F, Villamor N, Bellosillo B, Colomer D, Rozman M, Marce S, Lopez-Guillermo A, Campo E, Montserrat E: ZAP-70 expression as a surrogate for immunoglobulin-variableregion mutations in chronic lymphocytic leukemia. N Engl J Med 2003, 348: 1764-1775.

1 15. Zucchetto A, Bomben R, Dal Bo M, Nanni P, Bulian P, Rossi FM, Del Principe MI, Santini S, Del Poeta G, Degan M, Gattei V: ZAP-70 expression in B-cell chronic lymphocytic leukemia: evaluation by external (isotypic) or internal (T/NK cells) controls and correlation with IgV(H) mutations. Cytometry B Clin Cytom 2006, 70:284-292.

116. Del Principe MI, Del Poeta G, Buccisano F, Maurillo L, Venditti A, Zucchetto A, Marini R, Niscola P, Consalvo MA, Mazzone C, Ottaviani L, Panetta P, Bruno A, Bomben R, Suppo G, Degan M, Gattei V, de Fabritiis P, Cantonetti M, Lo Coco F, Del Principe D, Amadori S: Clinical significance of ZAP-70 protein expression in B-cell chronic lymphocytic leukemia. Blood 2006, 108:853-86I.

1 17. Marti G, Orfao A, Goolsby C: ZAP-70 in CLL: towards standardization of a biomarker for patient management: history of clinical cytometry special issue. Cytometry B Clin Cytom 2006, 70:197-200

1 18. Zenz T, Mertens D, Dohner H, Stilgenbauer S: Molecular diagnostics in chronic lymphocytic leukemia - pathogenetic and clinical implications. Leuk Lymphoma 2008, 49:864-873.

119. Chen L, Widhopf G, Huynh L, Rassenti L, Rai KR, Weiss A, Kipps T]: Expression of ZAP-70 is associated with increased B-cell receptor signaling in chronic lymphocytic leukemia. Blood 2002, 100:4609-46|4.

120. Efremov DG, Gobessi S, Longo PG: Signaling pathways activated by antigen-receptor engagement in chronic lymphocytic leukemia B-cells. Autoimmun Rev 2007, 7:102-108.

12I. Chen L, Apgar J, Huynh L, Dicker F, Giago-McGahan T, Rassenti L, Weiss A, Kipps TJ: ZAP-70 directly enhances IgM signaling in chronic lymphocytic leukemia. Blood 2005, 105:2036-204I.

122. Gobessi S, Laurenti L, Longo PG, Sica S, Leone G, Efremov DG: ZAP. 70 enhances B-cell-receptor signaling despite absent or inefficient tyrosine kinase activation in chronic lymphocytic leukemia and lymphoma B cells. Blood 2007, 109:2032-2039.

123. Ferrero E, Malavasi F: Human CD38, a leukocyte receptor and ectoenzyme, is a member of a novel eukaryotic gene family of nicotinamide adenine dinucleotide+-converting enzymes: extensive structural homology with the genes for murine bone marrow stromal cell antigen I and aplysian ADP-ribosyl cyclase. J Immunol 1997, 1 59:3858-3865.

124. Deaglio S, Aydin S, Vaisitti T, Bergui L, Malavasi F: CD38 at the junction between prognostic marker and therapeutic target. Trends Mol Med 2008, I 4:210-218.

125. Howard M, Grimaldi JC, Bazan JF, Lund FE, Santos-Argumedo L, Parkhouse RM, Walseth TF, Lee HC: Formation and hydrolysis of cyclic ADP-ribose catalyzed by lymphocyte antigen CD38. Science 1993, 262:1056-1059.

126. Ibrahim S, Jilani I, O'Brien S, Rogers A, Manshouri T, Giles F, Faderl S, Thomas D, Kantarjian H, Keating M, Albitar M: Clinical relevance of the expression of the CD3 I ligand for CD38 in patients with B-cell chronic lymphocytic leukemia. Cancer 2003, 97:1914-1919.

127. Hamblin TJ, Orchard JA, Gardiner A, Oscier DG, Davis Z, Stevenson FK: Immunoglobulin V genes and CD38 expression in CLL. Blood 2000, 95:2455-2457.
128. Del Poeta G, Maurillo L, Venditti A, Buccisano F, Epiceno AM, Capelli G, Tamburini A, Suppo G, Battaglia A, Del Principe MI, Del Moro B, Masi M, Amadori S: Clinical significance of CD38 expression in chronic lymphocytic leukemia. Blood 200I, 98:2633-2639.

129. Jelinek DF, Tschumper RC, Geyer SM, Bone ND, Dewald GW, Hanson CA, Stenson MJ, Witzig TE, Tefferi A, Kay NE: Analysis of clonal B-cell CD38 and immunoglobulin variable region sequence status in relation to clinical outcome for B-chronic lymphocytic leukaemia. Br J Haematol 200 I, I I 5:854-86 I.

130. Hamblin TJ, Orchard JA, Ibbotson RE, Davis Z, Thomas PW, Stevenson FK, Oscier DG: CD38 expression and immunoglobulin variable region mutations are independent prognostic variables in chronic lymphocytic leukemia, but CD38 expression may vary during the course of the disease. Blood 2002, 99: 1023-1029.

13I. Matrai Z: CD38 as a prognostic marker in CLL. Hematology 2005, 10:39-46.

132. Deaglio S, Vaisitti T, Bergui L, Bonello L, Horenstein AL, Tamagnone $L$, Boumsell L, Malavasi F: CD38 and CDI00 lead a network of surface receptors relaying positive signals for $B-C L L$ growth and survival. Blood 2005, 105:3042-3050.

133. Deaglio S, Vaisitti T, Aydin S, Bergui L, D'Arena G, Bonello L, Omede' P, Scatolini M, Jaksic O, Chiorino G, Efremov D, Malavasi F: CD38 and ZAP-70 are functionally linked and mark CLL cells with high migratory potential. Blood 2007, I I O(I 2):40 I2-2I.

134. Ghia P, Guida G, Stella S, Gottardi D, Geuna M, Strola G, Scielzo C, Caligaris-Cappio F: The pattern of CD38 expression defines a distinct subset of chronic lymphocytic leukemia (CLL) patients at risk of disease progression. Blood 2003, 101:1262-1269.

135. Jaksic O, Paro MM, Kardum SI, Kusec R, Pejsa V, Jaksic B: CD38 on $B$-cell chronic lymphocytic leukemia cells has higher expression in lymph nodes than in peripheral blood or bone marrow. Blood 2004, 103:1968-1969.

136. Patten PE, Buggins AG, Richards J, Wotherspoon A, Salisbury J, Mufti G], Hamblin TJ, Devereux S: CD38 expression in chronic lymphocytic leukemia is regulated by the tumor microenvironment. Blood 2008, II I:5 173-5I8I.

137. Burger JA, Tsukada N, Burger M, Zvaifler NJ, Dell'Aquila M, Kipps T): Blood-derived nurse-like cells protect chronic lymphocytic leukemia B cells from spontaneous apoptosis through stromal cell-derived factor-1. Blood 2000, 96:2655-2663.

138. Tsukada N, Burger JA, Zvaifler NJ, Kipps TJ: Distinctive features of "nurselike" cells that differentiate in the context of chronic lymphocytic leukemia. Blood 2002, 99:1030-1037.

139. Caligaris-Cappio F: Role of the microenvironment in chronic lymphocytic leukaemia. Br J Haematol 2003, I 23:380-388.

140. Deaglio S, Vaisitti T, Billington R, Bergui L, Omede' P, Genazzani AA, Malavasi F: CD38/CD 19: a lipid raft-dependent signaling complex in human B cells. Blood 2007, 109:5390-5398.

14I. Richardson SJ, Matthews C, Catherwood MA, Alexander HD, Carey BS, Farrugia J, Gardiner A, Mould S, Oscier D, Copplestone JA, Prentice AG: ZAP-70 expression is associated with enhanced ability to respond to migratory and survival signals in B-cell chronic lymphocytic leukemia (B-CLL). Blood 2006, 107:3584-3592.

142. Ottoson NC, Pribila JT, Chan AS, Shimizu Y: Cutting edge: $\mathbf{T}$ cell migration regulated by CXCR4 chemokine receptor signaling to ZAP-70 tyrosine kinase. J Immunol 200I, 167:|857-186I.

143. Ticchioni M, Charvet C, Noraz N, Lamy L, Steinberg M, Bernard A, Deckert M: Signaling through ZAP-70 is required for CXCLI 2-mediated T-cell transendothelial migration. Blood 2002, 99:3।II-3II8.

144. Kumar A, Humphreys TD, Kremer KN, Bramati PS, Bradfield L, Edgar CE, Hedin KE: CXCR4 physically associates with the T cell receptor to signal in T cells. Immunity 2006, 25:2 13-224.

145. de la Fuente MT, Casanova B, Moyano JV, Garcia-Gila M, Sanz L, Garcia-Marco J, Silva A, Garcia-Pardo A: Engagement of alpha4beta I integrin by fibronectin induces in vitro resistance of $B$ chronic lymphocytic leukemia cells to fludarabine. I Leukoc Biol 2002, 71:495-502.

146. Spessotto P, Cervi M, Mucignat MT, Mungiguerra G, Sartoretto I, Doliana R, Colombatti A: beta I Integrin-dependent Cell Adhe- 
sion to EMILIN-I Is Mediated by the gClq Domain. J Biol Chem 2003, 278:6160-6I67.

147. Eksioglu-Demiralp E, Alpdogan O, Aktan M, Firatli T, Ozturk A, Budak $T$, Bayik M, Akoglu T: Variable expression of CD49d antigen in B cell chronic lymphocytic leukemia is related to disease stages. Leukemia 1996, I0:1331-1339.

148. Zucchetto A, Benedetti D, Tripodo C, Bomben R, Dal BM, Marconi D, Bossi F, Lorenzon D, Degan M, Rossi FM, Rossi D, Bulian P, Franco V, Del PG, Deaglio S, Gaidano G, Tedesco F, Malavasi F, Gattei V: CD38/CD3 I, the CCL3 and CCL4 chemokines, and CD49d/ vascular cell adhesion molecule-I are interchained by sequential events sustaining chronic lymphocytic leukemia cell survival. Cancer Res 2009, 69:400I-4009.

149. Koopman G, Keehnen RM, Lindhout E, Newman W, Shimizu Y, van Seventer GA, de GC, Pals ST: Adhesion through the LFA-I (CDIIa/CDI8)-ICAM-I (CD54) and the VLA-4 (CD49d)VCAM-I (CD I06) pathways prevents apoptosis of germinal center B cells. J Immunol 1994, I 52:3760-3767.

150. Shanafelt TD, Geyer SM, Bone ND, Tschumper RC, Witzig TE, Nowakowski GS, Zent CS, Call TG, Laplant B, Dewald GW, Jelinek DF, Kay NE: CD49d expression is an independent predictor of overall survival in patients with chronic lymphocytic leukaemia: a prognostic parameter with therapeutic potential. $\mathrm{Br} J$ Haematol 2008, 140:537-546.

15I. Bulian P, Gaidano G, Del PG, Gattei V: CD49d expression in chronic lymphocytic leukemia: a prognostic parameter and a therapeutic target. Future Oncol 2008, 4:355-358.

152. Rossi D, Zucchetto A, Rossi FM, Capello D, Cerri M, Deambrogi C, Cresta S, Rasi S, De PL, Bodoni CL, Bulian P, Del PG, Ladetto M, Gattei $V$, Gaidano G: CD49d expression is an independent risk factor of progressive disease in early stage chronic lymphocytic leukemia. Haematologica 2008, 93:1575-1579.

153. Leger OJ, Yednock TA, Tanner L, Horner HC, Hines DK, Keen S, Saldanha J, Jones ST, Fritz LC, Bendig MM: Humanization of a mouse antibody against human alpha-4 integrin: a potential therapeutic for the treatment of multiple sclerosis. Hum Antibodies 1997, 8:3-16.

154. Kleinfield RW, Weigert MG: Analysis of VH gene replacement events in a B cell lymphoma. J Immunol 1989, I 42:4475-4482

155. Zhang Z, Burrows PD, Cooper MD: The molecular basis and biological significance of VH replacement. Immunol Rev 2004, 197:231-242.

156. Chiorazzi N, Hatzi K, Albesiano E: B-cell chronic lymphocytic leukemia, a clonal disease of B lymphocytes with receptors that vary in specificity for (auto)antigens. Ann N Y Acad Sci 2005, 1062:1-12.

157. Chiorazzi N, Ferrarini M: B cell chronic lymphocytic leukemia: lessons learned from studies of the $B$ cell antigen receptor. Annu Rev Immunol 2003, 21:84I-894.

158. Diamond B, Scharff MD: Somatic mutation of the TI5 heavy chain gives rise to an antibody with autoantibody specificity. Proc Natl Acad Sci USA 1 984, 8 I:584 I-5844.

159. Diaw L, Siwarski D, Coleman A, Kim J, Jones GM, Dighiero G, Huppi $\mathrm{K}$ : Restricted immunoglobulin variable region (Ig V) gene expression accompanies secondary rearrangements of light chain Ig V genes in mouse plasmacytomas. J Exp Med 1999, 190:1405-1416.

160. Deaglio S, Capobianco A, Bergui L, Durig J, Morabito F, Duhrsen U, Malavasi F: CD38 is a signaling molecule in B-cell chronic lymphocytic leukemia cells. Blood 2003, 102:2146-2155.

161. Foster AE, Brenner MK, Dotti G: Adoptive T-cell immunotherapy of chronic lymphocytic leukaemia. Best Pract Res Clin Haematol 2008, $21: 375-389$.

162. Lanham S, Hamblin T, Oscier D, Ibbotson R, Stevenson F, Packham G: Differential signaling via surface IgM is associated with $\mathbf{V H}$ gene mutational status and CD38 expression in chronic lymphocytic leukemia. Blood 2003, I 01 : I 087-1093.

163. Scielzo C, Ghia P, Conti A, Bachi A, Guida G, Geuna M, Alessio M, Caligaris-Cappio $\mathrm{F}$ : HSI protein is differentially expressed in chronic lymphocytic leukemia patient subsets with good or poor prognoses. J Clin Invest 2005, I I5:1644-1650.

164. Muzio M, Apollonio B, Scielzo C, Frenquelli M, Vandoni I, Boussiotis V, Caligaris-Cappio F, Ghia P: Constitutive activation of distinct BCR-signaling pathways in a subset of CLL patients: a molecular signature of anergy. Blood 2008, I | 2:188-195.
165. Ghia P, Scielzo C, Frenquelli M, Muzio M, Caligaris-Cappio F: From normal to clonal B cells: Chronic lymphocytic leukemia (CLL) at the crossroad between neoplasia and autoimmunity. Autoimmun Rev 2007, 7:|27-|3|.

166. Landgren O, Albitar M, Ma W, Abbasi F, Hayes RB, Ghia P, Marti GE, Caporaso NE: B-cell clones as early markers for chronic lymphocytic leukemia. N Engl J Med 2009, 360:659-667.
Publish with Biomed Central and every scientist can read your work free of charge

"BioMed Central will be the most significant development for disseminating the results of biomedical research in our lifetime. "

Sir Paul Nurse, Cancer Research UK

Your research papers will be:

- available free of charge to the entire biomedical community

- peer reviewed and published immediately upon acceptance

- cited in PubMed and archived on PubMed Central

- yours - you keep the copyright
BioMedcentral 